\title{
HUBUNGAN ANTARA KONSEP DIRI DENGAN DISIPLIN SISWA
}

\author{
Lina Novita $^{\text {a)}}$, Tustiyana Windiyani ${ }^{\text {a) }}$, Dina Aprilia Suhrawardi ${ }^{\text {a) }}$ \\ ${ }^{a)}$ Universitas Pakuan, Bogor, Indonesia \\ e-mail korespondensi : linovtaz@gmail.com
}

diterima: 20 Januari 2019; direvisi: 29 Januari 2019; disetujui: 24 Februari 2019

\begin{abstract}
This research is with the design and model of Quantitative Research of Correlational Studies. The purpose of this study is to describe the relationship between self-concept and students discipline of students in V grade students of Kota Batu 02 State Elementary School Ciomas District Bogor Regency. The subject of this research is 80 students of class V Kota Batu 02 State Elementary School Ciomas District Bogor Regency. This research was conducted on the odd semester of Lesson 2018/2019. The results showed that the average of self-concept variable is 89,88 , while the students discipline variable has an average of 90,95 thus the relationship of self-concept with students discipline in statistical analysis is indicated by the result of significance test and regression with regression equation $\hat{Y}=48,374+0,4737 x$. This means that each increase of one students discipline variable value is 0,4737 units. The strength of the relationship between self-concept and students discipline is shown by the correlation coefficient with $\mathrm{r}$ value of 0,48 which means have a relationship. The magnitude of the contribution of self-concept with students discipline is shown by the coefficient $\left(\mathrm{r}^{2}\right)$ of 0,23 with the coefficient of determination of $23 \%$. This means that the increase or decrease in students discipline has a relationship by self-concept by $23 \%$. Based on the results of the above research can be concluded that the relationship between self-concept and discipline of students in class V Kota Batu 02 State Element 02 Bogor Regency have a relationship.
\end{abstract}

Keywords: self-concept and students discipline

\section{PENDAHULUAN}

Disiplin memiliki peranan dalam berinteraksi di lingkungan keluarga, sekolah maupun masyarakat, artinya setiap individu dengan individu lain mempunyai kedisiplinan yang berbeda-beda, baik itu dari segi penampilan atau pun perilaku nya sehari-hari. Disiplin mempunyai serangkaian perilaku seseorang yang menunjukkan ketaatan dan kepatuhan terhadap peraturan, dan tata tertib yang berlaku karena dorongan dalam dirinya untuk melaksanakan tujuan belajar yang diinginkan. Tanpa disiplin yang baik, suasana sekolah dan kelas menjadi kurang kondusif bagi kegiatan pembelajaran.

Disiplin siswa di sekolah memiliki sikap ketaatan siswa dalam bertingkah laku. Sikap dan perilaku disiplin tidak akan terbentuk dengan sendirinya dalam waktu yang singkat, namun melalui proses yang cukup panjang. Terwujud melalui pembinaan yang dilakukan sejak dini di mulai dari lingkungan keluarga dan berlanjut dalam pendidikan di sekolah. Keluarga dan sekolah menjadi tempat penting bagi perkembangan disiplin siswa yang tidak akan terbentuk secara otomatis sejak manusia dilahirkan, melainkan terbentuk karena pengaruh lingkungannya.

Disiplin siswa juga menjadi salah satu kewajiban yang harus dilaksanakan oleh setiap siswa. Akan tetapi, kenyataan sehari-hari seringkali terjadi pelanggaran terhadap peraturan sekolah. Masih banyak siswa yang bertingkah laku kurang baik serta tidak dapat mengendalikan dirinya yang selalu berubah-ubah.

Dari hasil survey awal yang dilakukan pada siswa kelas V di Sekolah Dasar Negeri Kota Batu 02 Kecamatan Ciomas Kabupaten Bogor tentang kedisiplinan siswa, didapatkan hasil bahwa $66 \%$ atau 20 siswa melanggar kedisiplinan siswa seperti tidak memperhatikan guru saat kegiatan belajar, mencontek saat mengerjakan tugas di kelas, tidak memakai atribut lengkap, membuang sampah tidak pada tempatnya, tidak melaksanakan piket di kelas, terlambat datang ke sekolah, tugas yang tertinggal atau tidak dikerjakan oleh siswa, bertengkar saat jam pelajaran berlangsung, serta $34 \%$ atau 10 siswa yang mentaati kedisiplinan seperti memperhatikan guru saat kegiatan belajar, tidak mencontek saat mengerjakan tugas di kelas, memakai atribut lengkap, membuang sampah pada tempatnya, melaksanakan piket di kelas, datang ke sekolah tepat waktu, tertib di dalam kelas.

Perilaku tidak disiplin siswa seperti yang telah disebutkan di atas disebabkan oleh beberapa faktor. Faktorfaktor tersebut antara lain terdiri dari faktor eksternal dan faktor internal. Faktor eksternal yang mempengaruhi antara lain faktor non-sosial, seperti keadaan udara, waktu, tempat dan peralatan mau pun media yang dipakai untuk belajar, faktor sosial, terdiri atas lingkungan keluarga, lingkungan sekolah, dan lingkungan masyarakat. Faktor internal yang mempengaruhi antara lain faktor psikologi, seperti minat, motivasi, bakat, konsentrasi, dan kemampuan kognitif. Konsep diri yang rendah dapat menyebabkan kurangnya disiplin siswa.

Konsep diri erat kaitannya dengan disiplin. Sikap disiplin dan konsep diri yang tinggi penting dimiliki oleh setiap siswa. Disiplin dan konsep diri yang baik akan memudahkan siswa belajar secara teratur dan terarah. Konsep diri dan disiplin akan membantu siswa dalam berperilaku sehari-hari. Siswa yang memiliki konsep diri yang positif akan terlihat lebih optimis, penuh percaya diri dan selalu bersikap positif terhadap segala sesuatu. Sementara itu siswa yang memiliki konsep diri yang negatif akan cenderung bersikap pesimis terhadap kehidupan dan kesempatan yang dihadapinya.

Merujuk dari hasil penelitian terdahulu yang dilakukan oleh Monawati [1] tentang kedisiplinan siswa 
dalam proses belajar, kedisiplinan itu dapat menjadi alat untuk mencegah dan menjaga hal-hal yang dapat mengganggu dan menghambat proses belajar. Untuk itu berbagai peraturan ikut dibelakukan di sekolah-sekolah untuk menegakkan kedisiplinan siswa. Agar seorang siswa dapat belajar dengan baik maka ia harus bersikap disiplin, terutama disiplin dalam hal menepati jadwal pelajaran, disiplin dalam mengatasi godaan yang akan menunda waktu belajar, disiplin terhadap diri sendiri, dan disiplin dalam menjaga kondisi fisik agar selalu sehat. Selanjutnya hasil penelitian terdahulu Ambarwati [2] menunjukkan hasil penelitian konsep diri $67,74 \%$ siswa memiliki konsep diri sedang. Hal ini menunjukkan rata-rata siswa memiliki konsep diri yang cukup baik. Konsep diri siswa pada masa ini berkembang ke arah yang lebih ideal dan berubah sesuai perkembangannya.

Berdasarkan latar belakang di atas, maka peneliti tertarik untuk melakukan penelitian dengan judul "Hubungan antara Konsep Diri dengan Disiplin Siswa Kelas V Sekolah Dasar Negeri Kota Batu 02 Kecamatan Ciomas Kabupaten Bogor Tahun Pelajaran 2018/2019”. Pada penelitian ini peneliti memilih lokasi Sekolah Dasar Negeri Kota Batu 02 karena belum pernah dilakukan penelitian mengenai hubungan konsep diri dengan disiplin siswa

Ketaatan, kepatuhan terhadap tata tertib dapat terwujud apabila disiplin siswa dengan baik yang disertai kesadaran terhadap tindakan, norma dan kewajiban yang telah disepakati bersama. Definisi tersebut dikemukakan oleh Surya [3] yang menyatakan bahwa disiplin adalah tindakan yang dilakukan sesuai dengan ketentuan yang berlaku atau melakukan sesuatu sesuai dengan norma yang berlaku. Disiplin dengan kata lain, wajib mengikuti dan mentaati peraturan dan ketentuan yang sudah ditetapkan. Naim [4] disiplin adalah kepatuhan seseorang untuk menghormati dan melaksanakan suatu sistem yang mengharuskan orang untuk tunduk kepada keputusan perintah dan peraturan yang berlaku.

Kegiatan disiplin yang dilakukan siswa juga mengandung nilai-nilai atau norma yang menjadi acuan siswa dalam berdisiplin. Menurut Imron [5] ada tiga macammacam disiplin, yaitu: 1) Disiplin yang dibangun berdasarkan konsep otoritarian, 2) Disiplin yang dibangun berdasarkan konsep permissive, 3) Disiplin yang dibangun berdasarkan konsep kebebasan yang terkendali atau konsep kebebasan yang bertanggung jawab. Tidak semua individu memiliki pembawaan yang sama dan tidak semua keluarga memiliki kehidupan yang sama. Setiap keluarga pasti memiliki cara mendisiplinkan anak dengan cara tersendiri.

Dalam mendidik siswa perlu adanya disiplin yang baik, agar dapat merubah perilakunya yang sebelumnya tidak baik menjadi baik, maka dari itu perlu adanya upaya untuk mendisiplinkan siswa. Menurut Suryadi [6] upaya mendisiplinkan siswa yaitu penghargaan dalam menegakkan disiplin, karena banyak orangtua yang menganggap pujian atau hadiah tersebut hanya akan membuat siswa malas, dan mengejar prestasi semata-mata hanya memperoleh hadiah dan upaya mendisiplinkan siswa memberi hukuman secara efektif karena tanpa memberi hukuman siswa tidak akan mempelajari makna sesungguhnya dari benar dan salahnya perbuatan yang mereka lakukan.

Membiasakan siswa berdisiplin mempunyai pengaruh positif untuk siswa, berdasarkan pengalaman siswa yang memiliki disiplin yang baik maka akan berpengaruh baik juga terhadap lingkungan disekitar. Menurut Fadillah [7] upaya dalam mendisiplinkan siswa dapat dilakukan dengan cara membuat semacam aturan atau tata tertib yang wajib dipatuhi setiap siswa. Peraturan tersebut dibuat secara fleksibel tetapi tegas. Dengan kata lain peraturan dibuat menyesuaikan dengan kondisi perkembangan siswa serta dilaksanakan nya dengan penuh ketegasan. Disiplin merupakan pokok persoalan yang sangat penting bagi siswa, baik disiplin di lingkungan rumah maupun di lingkungan sekolah. Anitah [8] mengelompokkan menjadi tiga faktor yang mempengaruhi disiplin, yaitu : 1) Faktor fisik, 2) Faktor sosial, dan 3) Faktor psikologis.

Berdasarkan penjelasan uraian di atas dapat disintesiskan bahwa disiplin siswa adalah perilaku diri dari seorang siswa dengan penuh rasa kesadaran dalam diri siswa, ketaatan dalam mematuhi aturan serta kesediaan siswa untuk menjalankan semua peraturan, sesuai dengan norma dan aturan yang berlaku.

Konsep diri pada siswa sangat penting dibutuhkan karena mereka bisa secara tidak langsung mengenal pribadi mereka masing-masing. Agustiani [9] menyatakan konsep diri merupakan gambaran yang dimiliki seseorang tentang dirinya, yang dibentuk melalui pengalaman-pengalaman yang diperoleh dari interaksi dengan lingkungan. Menurut Dariyo [10] konsep diri merupakan gambaran diri sendiri yang bersifat menyeluruh terhadap keberadaan diri seseorang, artinya bahwa konsep diri seseorang dapat dinyatakan melalui pandangan seseorang tentang diri pribadinya.

Konsep diri merupakan aspek yang sangat penting bagi siswa dalam pola kepribadian setiap siswa, baik buruknya kepribadian siswa dapat dilihat dari tanda-tanda yang nampak pada diri siswa. Menurut Surya [11] disiplin siswa mempunyai 4 aspek. Keempat aspek tersebut yaitu: 1) Konsep diri dasar, 2) Konsep diri peralihan, 3) Konsep diri sosial, dan 4) Konsep diri ideal. Secara umum, faktor-faktor yang dapat mempengaruhi perkembangan konsep diri berbeda-beda tergantung pada sudut pandang setiap individu. Menurut Rakhmat [11] menyebutkan faktor yang mempengaruhi konsep diri adalah peranan orang lain dalam memahami diri sendiri. Adapun menurut Ubaedy [13] konsep diri itu dibangun yaitu: 1) Faktor Eksternal ini merupakan faktor yang dipengaruhi oleh ungkapan seseorang. 2) Faktor Internal merupakan konsep diri yang dibangun dari faktor internal ini sifatnya bukan lagi pilihan, melainkan kepastian.

Seiring dengan pertumbuhan dan perubahan fisik, kognitif dan kemampuan sosial anak usia sekolah dasar akan mengalami perubahan dalam pandangan terhadap dirinya sendiri dan setiap siswa semakin tumbuh besar akan mempengaruhi terhadap karakternya. Desmita [14] mengutip pendapat Santrock yang menyatakan perubahan-perubahan dalam konsep diri anak selama tahun-tahun sekolah dasar 
dapat dilihat sekurang-kurangnya dari tiga karakteristik konsep diri, yaitu: 1) Karakteristik internal, 2) Karakteristik aspek-aspek sosial, dan 3) Karakteristik perbandingan sosial.

Konsep diri memang tidak pernah terumuskan secara jelas dan stabil. Pemahaman diri selalu berubah-ubah, mengikuti perubahan yang setiap individu rasakan setiap saat. Menurut Novilita [15] konsep diri mempunyai beberapa dimensi yaitu: 1) Kemampuan mengontrol situasi (Control), 2) Kemampuan menanggung akibat dari situasi (Ownership dan Origin), 3) Kemampuan menghadapi kemalangan $($ Reach $), 4)$ Ketahanan diri dalam mempersepsi kemalangan (Endurance).

Berdasarkan uraian di atas, dapat disintesiskan bahwa konsep diri adalah konsep diri adalah penilaian dan pandangan seseorang tentang dirinya yang diakibatkan oleh pengalaman-pengalaman yang terjadi pada siswa.

\section{METODE PENELITIAN}

Penelitian dilakukan di kelas V Sekolah Dasar Negeri Kota Batu 02 Kecamatan Ciomas Kabupaten Bogor Semester Ganjil Tahun Pelajaran 2018/2019 yang dilakukan pada bulan Juli 2018. Populasi dalam penelitian ini adalah seluruh siswa kelas V Sekolah Dasar Negeri Kota Batu 02 Kecamatan Ciomas Kabupaten Bogor Semester Ganjil Tahun Pelajaran 2018/2019 yang berjumlah 80 orang siswa. Sampel yang digunakan dalam penelitian dilakukan teknik acak sederhana (simple random sampling) dengan rumus Taro Yamaro. Jumlah sampel penelitian sebanyak 44 orang siswa, masing-masing untuk kelas VA terdapat 22 siswa dan kelas VB terdapat 22 siswa.

Teknik pengumpulan data menggunakan angket (kuisioner) berupa pernyataan dengan 5 alternatif jawaban. Adapun alternatif jawabanya adalah pernyataan positif dari (5) Selalu, (4) Sering, (3) Kadang-kadang, (2) Pernah, (1) Tidak Pernah. .Sedangkan untuk pernyataan negatif. (1) Selalu, (2) Sering, (3) Kadang-kadang, (4) Pernah, (5) Tidak pernah.

Metode penelitian yang digunakan adalah metode penelitian survei dengan teknik korelasional.

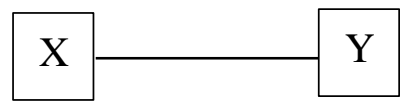

Keterangan:

$\mathrm{X}$ : variabel bebas (konsep diri)

Y: variabel terikat (disiplin siswa).

Gambar 1. Konstelasi Penelitian

\section{HASIL DAN PEMBAHASAN}

Deskripsi data hasil penelitian dikelompokan menjadi dua bagian yang terdiri dari: data variabel terikat Disiplin Siswa (Y), dan data variabel bebas Konsep Diri (X) yang dideskripsikan dalam bentuk deskriptif statistik. Deskripsi data masing-masing yaitu skor terendah, skor tertinggi, rentang skor, rata-rata (mean), nilai tengah (median), nilai yang sering muncul (modus), standar deviasi (SD), varians sampel, dan total skor.

Tabel 1.Distribusi Frekuensi Data Statistik Deskriptif Hasil Penelitian Variabel Konsep Diri (X) dan Variabel Disiplin Siswa (Y)

\begin{tabular}{lcc}
\hline \multicolumn{1}{c}{ Unsur Statistik } & Variabel X & Variabel Y \\
\hline Skor Minimum & 69 & 69 \\
\hline Skor Maximum & 98 & 98 \\
\hline Rentang Skor & 29 & 29 \\
\hline Rata-Rata(Mean) & 59.88 & 90,95 \\
\hline Median & 95,06 & 91 \\
\hline Modus & 96 & 91 \\
\hline Standar Deviasi (SD) & 6,054 & 5,917 \\
\hline Varians (G2) & 36,66 & 35,02 \\
\hline Total Skor & 3965 & 4002 \\
\hline
\end{tabular}

Gambaran data di atas dituangkan ke dalam tabel distribusi frekuensi dan histogram. Adapun tabel frekuensi dan histogram data variabel disiplin siswa (Y) sebagai berikut.

Tabel 2. Distribusi Disiplin Siswa (Y)

\begin{tabular}{|c|c|c|c|c|c|c|}
\hline No & $\begin{array}{c}\text { Interval } \\
\text { Kelas }\end{array}$ & $\begin{array}{l}\text { Batas } \\
\text { Kelas }\end{array}$ & $\begin{array}{c}\text { Titik } \\
\text { Tengah }\end{array}$ & fabsolut & fkum & $\begin{array}{c}\text { frelatif } \\
(\%)\end{array}$ \\
\hline 1 & $69-73$ & $68.5-73,5$ & 71 & 1 & 1 & $2 \%$ \\
\hline 2 & 74-78 & $73.5-78,5$ & 76 & 2 & 3 & $5 \%$ \\
\hline 3 & $79-83$ & $78,5-83,5$ & 81 & 3 & 6 & $7 \%$ \\
\hline 4 & $84-88$ & $83,5-88,5$ & 86 & 11 & 17 & $25 \%$ \\
\hline 5 & $89-93$ & $88,5-93,5$ & 91 & 16 & 33 & $36 \%$ \\
\hline 6 & $94-98$ & $93,5-98,5$ & 96 & 11 & 44 & $25 \%$ \\
\hline \multicolumn{3}{|c|}{ Jumlah } & - & 44 & - & $100 \%$ \\
\hline
\end{tabular}

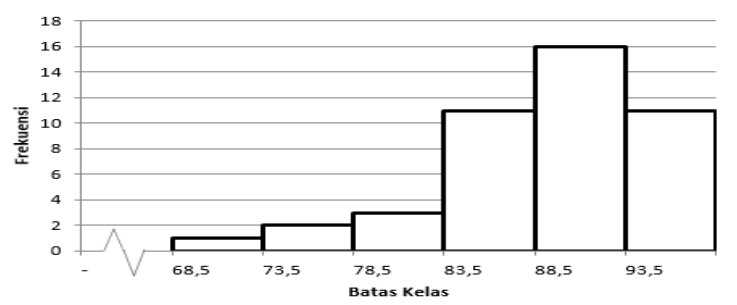

Gambar 2. Histogram Distribusi Frekuensi Skor Data Disiplin Siswa (Y)

Tabel 2. Distribusi Disiplin Siswa (Y)

\begin{tabular}{|c|c|c|c|c|c|c|}
\hline No & $\begin{array}{c}\text { Interval } \\
\text { Kelas }\end{array}$ & $\begin{array}{l}\text { Batas } \\
\text { Kelas }\end{array}$ & $\begin{array}{c}\text { Titik } \\
\text { Tengah }\end{array}$ & fabsolut & fkum & $\begin{array}{c}\text { frelatif } \\
\%)\end{array}$ \\
\hline 1 & $69-73$ & $68.5-73,5$ & 71 & 1 & 1 & $2 \%$ \\
\hline 2 & 74-78 & $73.5-78,5$ & 76 & 0 & 1 & $0 \%$ \\
\hline 3 & $79-83$ & $78,5-83,5$ & 81 & 4 & 5 & $10 \%$ \\
\hline 4 & $84-88$ & $83,5-88,5$ & 86 & 4 & 9 & $9 \%$ \\
\hline 5 & $89-93$ & $88,5-93,5$ & 91 & 20 & 29 & $45 \%$ \\
\hline 6 & $94-98$ & $93,5-98,5$ & 96 & 15 & 44 & $34 \%$ \\
\hline \multicolumn{3}{|c|}{ Jumlah } & - & 44 & - & $100 \%$ \\
\hline
\end{tabular}

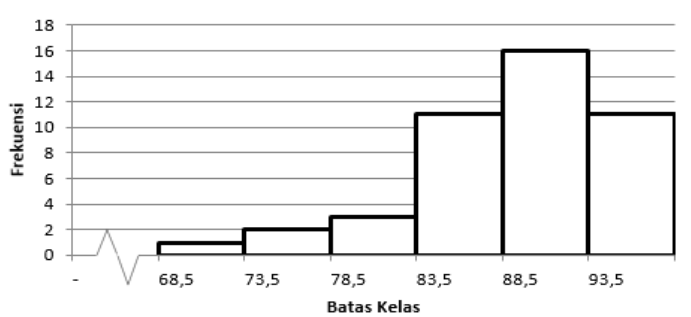

Gambar 3. Histogram Distribusi Frekuensi Skor Data Konsep Diri (X) 
Berdasarkan gambar histogram di atas, maka dapat diketahui bahwa frekuensi terbesar yaitu: 20, terdapat pada batas kelas 88,5-93,5, sedangkan frekuensi terkecil yaitu 0 , terdapat pada batas kelas 73,5-85,5.

\section{Pengujian Prasyarat Analisis}

1. Uji Normalitas Galat Taksiran

Uji normalitas ini dilakukan untuk mengetahui normal atau tidaknya suatu data. Untuk mengujinya yaitu dengan menggunakan uji Liliefors terhadap variabel konsep diri (X) dan variabel disiplin siswa $(\mathrm{Y})$ dengan syarat $: \mathrm{H}_{0}=$ $\mathrm{L}_{\text {hitung }}>\mathrm{L}_{\text {tabel }}$, berarti galat baku taksiran tidak normal. $\mathrm{H}_{\mathrm{a}}=$ $\mathrm{L}_{\text {hitung }}<\mathrm{L}_{\text {tabel }}$, berarti galat baku taksiran normal.

Untuk mengetahui uji normalitas galat baku pada variabel X dan Y, dapat dilihat pada tabel di bawah ini :

Tabel 4. Rangkuman Uji Normalitas Data Variabel (X) dan Variabel (Y)

\begin{tabular}{lcccc}
\hline No. & $\begin{array}{c}\text { Galat Baku } \\
\text { Taksiran }\end{array}$ & Lhitung & Ltabel & Kesimpulan \\
\hline $1 . \quad$ Variabel X dan Y & 0,0901 & 0,133 & Normal \\
\hline Syarat Normal Lhitung $<$ Ltabel & & \\
\hline
\end{tabular}

Berdasarkan perhitungan data variabel $\mathrm{X}$ dan $\mathrm{Y}$, dihasilkan Lhitung $=0,0901$. Harga tersebut dikonsultasikan dengan tabel Liliefors dengan $\mathrm{N}=44$ pada taraf signifikansi $5 \%$, maka harga Ltabel $=0,133$. Sehingga harga Lhitung <Ltabel ,maka distribusi data konsep diri (X) dengan disiplin siswa (Y) tersebut normal.

\section{Uji Homogenitas Varians}

Pengujian homogenitas dilakukan dengan Uji Fisher.

Tabel 5. Rangkuman Uji Homogenitas Konsep Diri (X) dengan Disiplin Siswa (Y)

\begin{tabular}{ccccc}
\hline $\begin{array}{c}\text { Varians } \\
\text { Yang diuji }\end{array}$ & Jumlah & \multicolumn{2}{c}{ F } & $\boldsymbol{\alpha}=\mathbf{0 , 0 5}$ \\
\cline { 3 - 4 } & sempel & F hitung & F tabel & \\
\hline Y atas X & 44 & 1.023 & 4.07 & Homogen \\
\hline Syarat Uji Signifikasi Fhitung $<$ Ftabel & & \\
\hline
\end{tabular}

Karena $F_{\text {hitung }}=1,023<F_{\text {tabel }}=4,07$ berarti data yang digunakan adalah homogen.

\section{Uji Regresi Linier Sederhana}

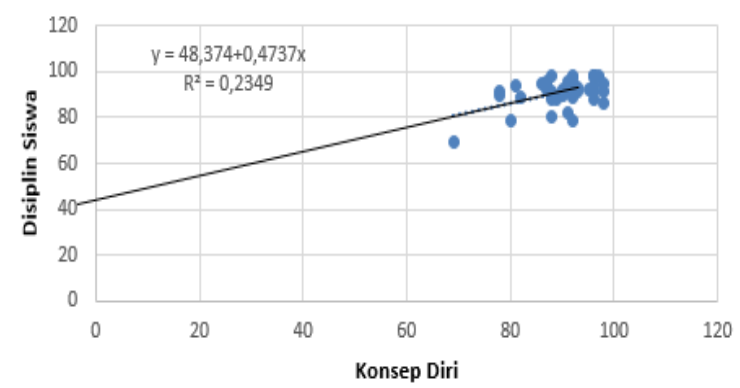

Gambar 6. Diagram Pancar Hubungan Fungsional Variabel Konsep Diri (X) dan Disiplin Siswa (Y)
Hubungan fungsional antara $\mathrm{X}$ dan $\mathrm{Y}$ di sajikan dalam bentuk $\hat{Y}=48,374+0,4737 x$ dengan $X$ adalah signifikan.

\section{Uji Signifikasi Regresi}

Berdasarkan hasil perhitungan uji signifikasi regresi diperoleh $\mathrm{F}_{\text {hitung }}=12,764$ dengan $\mathrm{F}_{\text {tabel }(\mathrm{a}=0,05)}=4,07$ dan $\mathrm{F}_{\text {tabel }}$ ${ }_{(\mathrm{a}=0,01)}=7,28$. Dengan demikian $\mathrm{F}_{\text {tabel }}(\mathrm{a}=0,05)<\mathrm{F}_{\text {tabel }}$ $(\mathrm{a}=0,01)<\mathrm{F}_{\text {hitung }}=4,07<7,28<12,764$. Berarti hubungan fungsional antara konsep diri dengan disiplin siswa yang ditunjukan oleh persamaan regresi yaitu sangat signifikan.

\section{Uji Linearitas Regresi}

Pengujian linearitas regresi disiplin siswa $(\mathrm{Y})$ dengan konsep diri $(\mathrm{X})$, didapatkan nilai $\mathrm{F}_{\text {hitung }}=-1,931$ sedangkan $\mathrm{F}_{\text {tabel }}=2,03$ dengan $\mathrm{dk}$ pembilang $=15$ dan $\mathrm{dk}$ penyebut $=$ 29. Persyaratan persamaan regresi dikatakan linear apabila $F_{\text {hitung }}<F_{\text {tabel }}$. Berdasarkan hasil perhitungan $F_{\text {hitung }}=-1,931<$ $\mathrm{F}_{\text {tabel }}=2,03$. Dengan demikian maka persamaan regresi $\hat{\mathrm{Y}}=48,374+0,4737 \mathrm{x}$ adalah linear. Kesimpulannya antara data konsep diri dengan disiplin siswa memiliki pola hubungan yang linear.

6. Pengujian Hipotesis Statistik $\left(\mathrm{H}_{\mathrm{o}}\right.$ dan $\left.\mathrm{H}_{\mathrm{a}}\right)$

Hasil perhitungan uji signifikasi digambarkan pada kurva penolakan dan penerimaan $\mathrm{H}_{0}$ berikut :

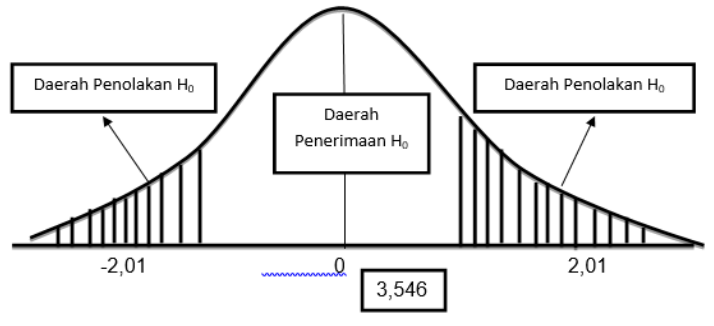

Gambar 7. kurva penolakan dan penerimaan H0 pada Variabel Konsep Diri (X) dengan Disiplin Siswa (Y)

Berdasarkan kurva di atas apabila $t_{\text {hitung }}$ terletak antara -2,01 dan 2,01 maka $\mathrm{H}_{0}$ diterima, tetapi apabila $\mathrm{t}_{\text {hitung }}$ tidak terletak antara -2,01 dan 2,01 maka $\mathrm{H}_{\mathrm{a}}$ diterima. Oleh karena didapat $t_{\text {hitung }}=3,546$ maka hasil penelitian adalah $\mathrm{H}_{0}$ ditolak dan $\mathrm{H}_{\mathrm{a}}$ diterima. Dengan demikian dapat disimpulkan bahwa terdapat hubungan antara konsep diri dengan disiplin siswa.

\section{Pengujian Hipotesis Penelitian}

1. Uji Koefisien Korelasi

Berikut tabel tentang perhitungan hipotesis penelitian variabel konsep diri (X) dengan Disiplin Siswa (Y)

Tabel 7. Hasil Perhitungan Uji Signifikasi Korelasi Variabel Konsep Diri (X) dengan Disiplin Siswa (Y)

\begin{tabular}{|c|c|c|c|c|c|c|}
\hline \multirow[t]{2}{*}{$\mathbf{N}$} & \multirow{2}{*}{$\begin{array}{c}\text { Koefisien } \\
\text { Korelasi }\end{array}$} & \multirow[t]{2}{*}{$\overline{D k}$} & \multicolumn{2}{|l|}{$t_{\text {tabel }}$} & \multirow[t]{2}{*}{$\mathbf{t}_{\text {hitung }}$} & \multirow[t]{2}{*}{ Kesimpulan } \\
\hline & & & $(\alpha=0,05)$ & $(\alpha=0.01)$ & & \\
\hline 44 & 0,48 & 42 & 2,01 & 2,69 & 3,546 & Signifikan \\
\hline
\end{tabular}

Berdasarkan hasil perhitungan $t_{\text {hitung }}=3,546$ dengan $t_{\text {tabel }(\alpha=0,05)}=2,01$ dan $t_{\text {tabel }(\alpha=0,01)}=2,69$. Dengan demikian, $t_{\text {hitung }}>t_{\text {tabel }(\alpha=0,05)}>t_{\text {tabel }(\alpha=0,01)}=3,546>2,01$ yang berarti 
koefisien korelasi konsep diri dengan disiplin siswa dinyatakan signifikan, yang artinya bahwa terdapat hubungan positif dan signifikan antara konsep diri dengan disiplin siswa.

2. Perhitungan Koefisien Determinasi

Berdasarkan perhitungan koefisien determinasi nilai $r^{2}=0,23$ dengan koefisien determinasi $23 \%$, dari data tersebut dapat dirumuskan bahwa disiplin belajar dapat berperan dengan memberkontribusi sebesar $23 \%$ terhadap hasil belajar siswa. Sedangkan $77 \%$ hasil belajar dipengaruhi oleh faktor-faktor lain.

Hasil analisis data dan pengujian Hasil analisis data pengujian hipotesis data bahwa terdapat hubungan yang positif antara konsep diri terhadap disiplin siswa. Hal ini menunjukan bahwa hipotesis penelitian diterima, berarti konsep diri memberikan kontribusi dalam disiplin siswa.

Hubungan fungsional antara konsep diri dengan disiplin siswa secara analisis statistik ditunjukan dengan hasil uji signifikasi dan regresi $\hat{Y}=48,374+0,4737 x$. Hal ini berarti bahwa setiap kenaikan satu unit variabel konsep diri menyebabkan peningkatan pada disiplin siswa.

Kekuatan hubungan konsep diri dengan disiplin siswa ditunjukkan dengan koefisien korelasi sebesar 0,48. Harga koefisien tersebut menunjukan bahwa terdapat hubungan yang sedang antara konsep diri dengan disiplin siswa ditunjukan dengan determinasi $\left(r^{2}\right)$ sebesar 0,23 . Hal tersebut berarti bahwa penaikan dan penurunan disiplin siswa dipengaruhi oleh tingkat konsep diri sebesar 23\%, sedangkan sisanya $77 \%$ dipengaruhi oleh faktor-faktor lain.

Dalam mendisiplinkan siswa sikap, penampilan, dan tingkah laku tersebut merupakan cerminan seseorang atau karakter seseorang untuk bisa menjadi pribadi yang disiplin dengan baik. Pada hasil penelitian Budiarnawan [16], menunjukkan hasil bahwa konsep diri, pola asuh orang tua berhubungan secara signifikan terhadap hasil belajar IPA siswa kelas V SD di Desa Selat. Data yang diambil dengan menggunakan kuisioner. Data penelitian selanjutnya dianalisis dengan teknik statistic yaitu regresi sederhana, product moment dan regresi ganda. Hasil penelitian menunjukkan hubungan antara konsep diri dan hasil belajar IPA $F_{\text {hitung }}=5,40>F_{\text {tabel }}=3,94$. Hubungan antara pola asuh orang tua dan hasil belajar IPA $\mathrm{F}_{\text {hitung }}=53,32>\mathrm{F}_{\text {tabe }} \mathrm{l}=3,94$. Hubungan secara bersama-sama antara konsep diri dan pola asuh orang tua terhadap hasil belajar IPA $\mathrm{F}_{\text {hitung }}=31,34>\mathrm{F}_{\text {tabel }}=3,94$, yang berarti memiliki hubungan yang signifikan.

Adapun hasil penelitian yang telah dilakukan Monawati [1] dengan pendekatan yang digunakan dalam penelitian ini adalah pendekatan kualitatif dengan jenis penelitian deskriptif. Teknik pengumpulan data dilakukan melalui observasi,wawancara, dan dokumentasi. Teknik analisis data dilakukan melalui data reduction, data display, dan verification serta menggunakan rumus persentase dan rumus rata-rata. Hasil analisis data menunjukkan bahwa kedisiplinan memiliki hubungan terhadap hasil belajar siswa. Dari 6 siswa, 4 siswa yang tingkat kedisiplinan dan hasil belajarnya sesuai sedangkan 2 siswa lagi tingkat kedisiplinan dan hasil belajarnya kurang sesuai. Ini berarti tingkat kesesuaian antara kedisiplinan dengan hasil belajar siswa berada pada kategori sedang $(66,7 \%)$. Simpulan penelitian ini adalah bahwa kedisiplinan mempengaruhi hasil belajar tetapi tidak sepenuhnya hasil belajar dipengaruhi oleh kedisiplinan. Hal ini dikarenakan hasil belajar tidak hanya dipengaruhi oleh kedisiplinan saja tetapi juga dipengaruhi oleh faktor-faktor yang lain seperti keluarga, sekolah, masyarakat, minat, kecerdasan, bakat, motivasi, dan sebagainya.

Selanjutnya hasil penelitian Yasmin [17], menunjukkan bahwa terdapat hubungan disiplin dengan tanggung jawab belajar. Penelitian lainnya dilakukan oleh Zainidar [18], Bedasarkan hasil penelitian diperoleh nilai koefesien korelasi ( $\mathrm{r}$ ) $=0,59$ dimana nilai tersebut menjelaskan adanya pengaruh positif dan signifikan antara disiplin belajar terhadap hasil belajar siswa kelas IV SD Negeri Banda Aceh. Dari hasil pengujian data diperoleh nilai $r$ hitung sebesar 0,59 sementara $r$ tabel 0,361 pada taraf signifikasi 5\%. Dengan demikian hipotesis nol (Ho) dinyatakan ditolak, sedangkan hipotesis penelitian (Ha) dinyatakan diterima, artinya bahwa terdapat korelasi positif antara disiplin belajar terhadap hasil belajar siswa kelas IV SD Negeri Banda Aceh memiliki korelasi yang cukup. Penelitian yang dilakukan Rachmawati [19], menggunakan metode kuantitatif deskriptif, menunjukkan bahwa disiplin belajar memberikan kontribusi terhadap hasil belajar siswa. Sedangkan $32 \%$ dipengaruhi oleh faktor lain yang tidak diteliti dalam penelitian ini.

Kelima penelitian yang telah dilakukan tersebut memiliki perbedaan dalam bentuk metode dan objek yang diteliti. Persamaannya terletak pda salah satu variabel, yaitu disiplin belajar. Dengan demikian jelas bahwa disiplin belajar memiliki hubungan dengan hasil belajar.

\section{SIMPULAN}

Simpulan penelitian dapat dipaparkan bahwa terdapat hubungan positif yang signifikan antara Konsep Diri dengan Disiplin Siswa kelas V di SDN Kota Batu 02 Kecamatan Ciomas Kabupaten Bogor Semester Ganjil Tahun Pelajaran 2018/2019. Hasil penelitian menunjukkan bahwa terdapat hubungan antara Konsep Diri dengan Disiplin Siswa koefisien regresi (rxy) sebesar 0,48 dan diperoleh $t_{\text {hitung }}$ sebesar 3,546. Hal ini menunjukkan adanya hubungan yang positif antara Konsep Diri dengan Disiplin Siswa, sedangkan koefisien determinasi $\left(\mathrm{r}^{2}\right)$ sebesar $0,23 \%$ atau sebesar $23 \%$. Hal ini dapat ditunjukkan dari persamaan regresi $\hat{Y}=48,374+0,4737 x$ yang berarti tiap peningkatan satu unit konsep diri akan meningkatkan disiplin siswa sebesar 0,4737 unit. Konstribusi variabel Konsep Diri dalam meningkatkan Disiplin Siswa sebesar 0,23 atau sebanyak $23 \%$.

\section{REFERENSI}

[1] Monawati. 2016. "Hubungan Antara Kedisiplinan Terhadap Hasil Belajar Siswa Kelas V Di SD Negeri 
10 BandaAceh"Jurnal Ilmiah Mahasiswa Prodi PGSD. Vol.1 (1).

[2] Ambarwati. 2016. "Hubungan Konsep Diri dengan Interaksi Sosial Siswa Kelas IV SD" Jurnal Pendidikan Guru Sekolah Dasar. Vol.1(4). h.927.

[3] Surya, Mohamad. 2010. Landasan pendidikan. Bogor: Ghalia.

[4] Naim, Ngainun. 2012. Character Building Optimalisasi PeranPendidikan dalam Pengembangan Ilmu \& Pembentukan Karakter Bangsa. Jogjakarta: Ar-Ruzz Media.

[5] Imron.2012.Manajemen peserta didik berbasis sekolah. Jakarta: Bumi aksara.

[6] Suryadi. 2007. Cara efektif memahamiperilaku anak usia dini. Jakarta: EDSA.

[7] Fadlillah.2013.Pendidikan Karakterusia dini. Jogjakarta: AR-Ruzz media.

[8] Anitah, Sri. 2007. Strategi Pembelajaran di SD. Jakarta: Universitas Terbuka.

[9] Agustiani. 2009. PsikologiPerkembangan. Bandung: Refika.

[10] Dariyo. 2007. Psikologi Perkmbangan. Bandung: Refika.

[11] Surya, Moch. 2013. Psikologi GuruKonsep dan Aplikasi. Bandung: Alfabeta.

[12] Rakhmat. 2011. Psikologi Komunikasi. Bandung: Remaja

[13] Ubaedy. 2013. Total confidence. Jakarta: Bee Media Pustaka.

[14] Desmita. 2016. Psikologi Perkembangan Peserta Didik. Bandung: Remaja

[15] Novilita. 2013. "Konsep Diri Adversity Quotient dan Kemandirian Belajar Siswa" Jurnal Psikologi. Vol.8(1).h.619-632.

[16] Budiarnawan. 2014. "Hubungan Antara Konsep Diri dan Pola Asuh Orang Tua Terhadap Hasil Belajar IPA Siswa Kelas V SD Di Desa Selat" Jurnal Mimbar PGSD Universitas Pendidikan Ganesha. Vol. 2(1).

[17] Yasmin. 2016. "Hubungan Disiplin dengan Tanggung Jawab Belajar Siswa” Jurnal Pendidikan.Vol.1(4).h.i.

[18] Zainidar. 2017. "Hubungan Disiplin Belajar Terhadap Hasil Belajar Siswa Kelas IV Sekolah Dasar Negeri 18 Banda Aceh" Jurnal Ilmiah Pendidikan Guru Sekolah Dasar. Vol.2(1).h.i.

[19] Rachmawati. 2014. "Hubungan Disiplin Belajar dengan Hasil Belajar Siswa Pada Mata Pelajaran PKN Di Sekolah Negeri Sumber Jaya 04 Tambun Selatan Kabupaten Bekasi”. Pedagogik. vol.2 (2). h.i. 